Article

\title{
Business Models of Social Enterprises: Insight into Key Components and Value Creation
}

\author{
Petra C. M. Neessen (D), Cosmina L. Voinea *(D) and Els Dobber \\ Faculty of Management, Open Universiteit, 6401 DL Heerlen, The Netherlands; petra.neessen@ou.nl (P.C.M.N.); \\ els.dobber@gmail.com (E.D.) \\ * Correspondence: cosmina.voinea@ou.nl
}

Citation: Neessen, P.C.M.; Voinea, C.L.; Dobber, E. Business Models of Social Enterprises: Insight into Key Components and Value Creation. Sustainability 2021, 13, 12750. https://doi.org/10.3390/ su132212750

Academic Editor:

Izabela Jonek-Kowalska

Received: 8 September 2021

Accepted: 13 October 2021

Published: 18 November 2021

Publisher's Note: MDPI stays neutral with regard to jurisdictional claims in published maps and institutional affiliations.

\begin{abstract}
The increasing pressure on people to do something for society, in combination with the need for financial turnover in order to survive, is seen as one of the dominant factors for the rise of social enterprises. However, there is still debate on how social enterprises create social value in addition to economic value and how this is reflected in the business model. In this case study research, we investigate how the key components of the business model of social enterprises contribute to the creation of social and economic value. The cases in this research create social and economic value through the mutually interacting operation of key components and their sub-components. This interacting effect focuses on the one hand on the alignment of the internal architecture, market and financial management with the mission. The mission statement serves as a guiding principle. Furthermore, realizing the highest possible profit is not a goal in itself for social entrepreneurs. Generating profit serves the continuity of the company and the realization of social value. We also found that social enterprises can be configured as either market hybrids, blending hybrids, bridging hybrids or coupling hybrids.
\end{abstract}

Keywords: business models; social enterprises; value creation

\section{Introduction}

The sustainability debate has increased in recent years. Globally, we face complex challenges such as the depletion of natural resources, the negative effects of environmental degradation, the fact that billions of citizens still live in poverty and that there are huge disparities in opportunity, wealth and power [1]. Given this context, business model innovation is increasingly recognized as a means of achieving greater social and environmental sustainability $[2,3]$. The current COVID-19 pandemic is also increasing the call for economic investments and activities that lead to a more sustainable world [4]. A whole range of organizations are, in response to the abovementioned challenges, concerned with aspects of sustainability and social innovations, including non-profit organizations, commercial enterprises with CSR/CSR objectives and social enterprises [5-9].This research focuses specifically on the business models of social enterprises.

The business model of an organization offers insight into how a company performs [10], realizes competitive advantage [11] and creates value [12]. However, there is still no consensus on the definition of a business model and what the key components of a business model are $[13,14]$. One aspect that has resonated with many researchers is that a business model is a holistic unit of analysis that explains how companies do business, create and capture value [2]. When discussing sustainability in relation to value creation, it is important to notice that value creation is not only about economic value, but also about social and environmental value $[12,15,16]$. Several researchers identify a gap with regard to research into sustainable business models in the literature $[12,15,16]$. The missing central place of profit generation in sustainable business models has not yet been well researched. How can sustainable business models function and create social and environmental value without focusing on generating profit [5]? 
This study focuses on a specific type of sustainable business, namely social enterprises. There are about 5000-6000 social enterprises, good for about $65,000-80,000$ jobs in the Netherlands. They mostly operate within two (out of eight) impact areas: the circular economy (25\%) and labor participation and equality (20\%) [17]. According to the Social Enterprise Monitor [18], this sector is growing by $10 \%$ per year, and the percentage of social enterprises that are not making a loss is increasing. Furthermore, $44 \%$ of the 168 social enterprises surveyed indicate in the above-mentioned Monitor that they are making a profit, while $28 \%$ are still making a loss. Compared to a non-profit organization, a social enterprise can therefore make a profit, but primarily pursues a social goal [19]. According to Yunus et al. [13], a social enterprise is a new form of business that can be placed somewhere between a profit-maximizing and a non-profit organization. Partly because it is still a relatively young research topic, there is no general consensus on the definition of social enterprise $[20,21]$. The definitions often contain the element of independent entrepreneurship and a social objective [20]. This research aims to connect the research gaps of the under-investigated area of business models of social enterprises, as well as the value creation within these social enterprises. The research question is therefore: "How do key components of the business model of social enterprises contribute to the creation of social and economic value?"

This research is relevant from a scientific point of view. There is neglect spotting, in the sense that the research area is underexposed [22]. As mentioned above, the innovation of business models is increasingly recognized as a way to deliver greater social and environmental sustainability [3]. How these sustainable business models work, including those of social enterprises, is still insufficiently understood [5,23].

This study is relevant from a practical point of view. Phillips et al. [24] argue that the shrinking public sector and pressure on the classic, profitable business model are reasons for the increased interest in social enterprises and social innovation in recent years. The apparent added value of social innovation is seen as an untapped opportunity for commercial organizations. Managers of these companies could therefore learn something from social enterprises. It is also important for social entrepreneurs to better understand what works and what does not. Are there sound business cases that can run in the long term without public funding?

\section{Theoretical Framework}

\subsection{Social Enterprise}

The increasing pressure on people to do something for society, in combination with the need for financial turnover in order to survive, is seen as one of the dominant factors for the rise of social enterprises [19]. This combination of having a social impact on society but also the need for certain economic revenue to sustain in the future is what defines a social enterprise and separates these organizations from non-profit organizations [25-27]. This balance is also reflected in their organizational characteristics [28]. On the one hand, there are economic characteristics (e.g., continuous production, economic risk), but on the other hand, there are social elements, for instance, that they produce benefits for society, have inclusive governance and that profits are distributed in a limited fashion $[9,26,28]$. Social enterprises are therefore placed somewhere in the middle of the continuum "oriented towards social value" versus "oriented towards financial value [29]". The emergence of the social enterprise is often placed in the context of market or government failure [30-32]. Despite the increased attention [25,33], the debate on how to define social enterprise is still unresolved [34]. Dacin et al. [20] found 37 definitions around this topic. The common denominator of the definitions used seems to be the characteristics of the underlying activities $[35,36]$. The social enterprise has a so-called color locale [36]. For example, social enterprises in the United States correspond to the market-based approaches related to income generation and social change [35], while in Europe the social enterprise has roots in the cooperative tradition of the social collective system [19]. 
Regarding the definition of social enterprises, there are authors who ignore the economic outcome of social enterprises and focus primarily on the creation of social value by providing solutions to social problems $[36,37]$. Other authors associate economic value with these types of organizations, despite it not being the primary mission $[19,35,38,39]$. There are authors who see a social enterprise as a marriage between the two, seemingly contradictory, organizational goals; creating social and economic value through market-based organizational forms [34,38]. Organizations that combine a social and/or environmental mission with creating economic value are also called hybrid organizations [39]. Finally, the EMES network defines a social enterprise as: "organizations with an explicit aim to benefit the community, initiated by a group of citizens and in which the material interest of capital investors is subject to limits" [27].

In this study, a specific definition of social enterprise is used. This definition is based on the definition of the European Commission. A social enterprise operates primarily on the basis of a social mission (impact first). It realizes impact as an independent company that provides a service or product and has a revenue model. The social enterprise sees profit as a means, not as an end. It is transparent, run in a social way, is fair to everyone. Management and policies are based on a balanced control for stakeholders.

\subsection{The Business Model of Social Enterprises}

Despite the general increase in the literature on business models, scientists do not agree on what a business model is [2]. However, there are common denominators and themes within the research area. These themes are the unit of analysis of the company, the boundaries and the approach of these companies in the way of doing business. This explains the value creation of the companies [2].

A lot of research is done on the business model concept of an organization because it offers insight into how a company performs [10] realizes competitive advantage [11] and creates value [12]. The literature shows that social enterprises use different business models as compared to other enterprises [40].

The relevance of business models for (sustainable) business performance is recognized in the literature [10]. In 2004, Osterwalder described the ontology study of business models. The Business Model Canvas (BMC) derived from this ontology [41] provides a simple, one-page, visual canvas, consisting of nine building blocks, that is used to help design and understand a given business model. Business models describe the elements and relationships of a company [14]. Michelini and Fiorentino [14] have mapped out which components of a business model are highlighted by various authors, such as strategy, resources, customer interface, competitors, channels, structure et cetera [2,42]. Although the BMC of Osterwalder and Pigneur [41] has become a popular reference standard and is taught worldwide in management and entrepreneurship education [43], the literature also argues that the BMC does not fully represent the business model of a social company. For example, Qasharin [44] argues for the addition of extra building blocks to understand how a social enterprise creates, delivers and retains social value. In her research on various modified canvases for social enterprises, she recommends including the blocks "mission" and "impact and measurement". The mission block is about the purpose, the reason for the existence of the social enterprise, acting as a guideline for the enterprise. The impact and measure block describes the benefits to the social enterprise's customers and the success and progress indicators that are measured [45]. According to Mair et al. [46], the components of a social entrepreneurial model are; the issue domain in which social enterprises want to make a difference, the target groups they want to involve in the working method and the activities in which they are active. Yunus et al. [16] propose an element-based aggregated level approach with the three components: value proposition, value architecture and profit equation. Jonker et al. [15] explicitly abandon what they call the "traditional business model" because it is implicitly based on organizing within an organization, while value creation in their view is a shared task and about the creation of multiple values. Jonker et al. [15] distinguish the following elements with regard to the new 
business models for sustainable companies that they examined: (1) a basic logic (the values and principles that the parties share); (2) strategic choices that are made, (3) developing and maintaining a value network, and (4) organizing cooperatively [13]. For Jonker et al. [15] these elements are "the building blocks for mutual value creation and at the same time are the entry barrier for competitors." (p. 14). A network within environment is important [47]. From the hybrid organization literature, the following elements of a social business model should be considered [42,48,49]: (1) The mission should be defined around a social purpose. It creates a long-term mind-set. The trade-off between the social and the economic benefits could be tackled by creating a synergy between them. (2) The relationship between the organization and the stakeholders is crucial. (3) The social hybrid organizations do not seek growth by dominating the industry and the market but are aware that a certain growth and the ability to scale is needed to create social change. Also these organizations can act as examples for others [40,48]. These elements of hybrid organization are recognizable in the elements of social enterprises. Several researchers have stated that social enterprises create value via cooperation and collective action, multi-stakeholder governance, assets socialization and the motivation of its initiators and employees $[9,27]$.

To summarize, the relevance of business models for business performance in general and for sustainability is recognized in the literature [10]. There is no clear picture of which key components are part of the business model [14], especially in relation to social enterprises. To understand the specifics of social business models, it is important to understand the relationship between the actions taken and their social impact [49]. In conjunction with the purpose of this research and taking into account the specificities of social business models and the scientific literature, the following proposition is formulated:

Proposition 1: The mission, the internal architecture, the financial management and the market are characteristic key components of the business model of a social enterprise.

Based on the literature, it is also plausible to assume that these key components are each further characterized by several sub-components. These sub-components will be determined on the basis of the analysis of the research results.

Based on the work of Qasharin [44] and Mair et al. [46], the following proposition has been formulated:

Proposition 2: The mission of a social enterprise provides direction for the way in which other key components are implemented.

\subsection{Economic and Social Value}

In the past century, the success of companies was mainly measured by the financial performance of shareholders [43]. Thanks to the sustainability debate, the one-dimensional, purely economic value creation perspective on business models are up for discussion and the multiple value creation perspective wins in strength [50]. Several researchers in the field of social and sustainable organizations $[14,15,32]$ refer to the much-cited work of Porter and Kramer [12] in relation to value. These authors draw attention to the use of a broader definition of value by companies. They argue that in a narrow definition, value is associated only with short-term financial performance for shareholders, while the company's long-term success is also determined by customer needs and broader influences. According to the researchers, the solution would lie in applying a "shared value principle" whereby economic value is created in such a way that it also generates social value for society by meeting its needs and challenges. Jonker et al. [15] talk about multiple values: economic, social and ecological values. Another stream of literature, focusing on hybrid organizations, elicits the importance of combining social and economic value as well. They argue that creating a hybrid value gives room to innovative solutions. These innovative solutions can possibly ensure the survival of these organizations [39,51]. In this study, the dual variant - economic and social value-is used, as it ties in with the hybrid nature of social enterprises, in which the social mission and entrepreneurial activities are combined [34]. Social value has a broad meaning and therefore relates to both people and the environment [52]. Economic value is defined as the financial gain for the company's 
shareholders or owners and social value is the value that the organization creates for society in achieving its mission [32].

Based on previous research, the following proposition (3) has been formulated: Social enterprises develop and maintain cross-organizational networks to jointly create social value.

\subsection{Configuration of Business Models of Social Enterprises}

Research shows that social enterprises are vulnerable due to the tension arising between the pursuits of social value on the one hand and economic value on the other, resulting in the possibility of missionary drive or the lack of financial sustainability [32]. So it helps to identify how leaders are able to meet these challenges and how social enterprises are classified according to a specific type of enterprise [46,52,53].

Typologies are a product of deductive research. The major advantage of typologies is their ability to simplify complex concepts by classifying objects according to a few criteria at a timev [54,55]. There are different ways to classify a social enterprise. The classification is important because each type is based on different business models, challenges and (earning) strategies $[29,46,56,57]$. Several researchers recognize that it is difficult to define the characteristics of social enterprises and their limits [34]. Criteria that are used to characterize social enterprises are, for example, on the basis of origin, area of impact, entrepreneurship dimension and scope of ambition (local versus national versus global) or a combination of these criteria [29]. For example, Mair et al. [46] identify four ideal types based on impact: political (law and rights), human (environment, education and health), economic (poverty, working conditions and labor participation) and social (networking). These types are each associated with a different logic that may explain the difference between the organizations. In comparison, according to the Social Enterprise Monitor 2018, a survey based on 168 respondents [18], social enterprises in the Netherlands focus on: labor participation (44\%), environment (24\%), well-being (26\%) and international development (6\%).

Santos et al. [32] arrive at a different classification, namely a classification based on the dimensions of value spillover and the extent of overlap between customers and beneficiaries. Value spillover is the increase or decrease of another value as a result of a transaction. The purchase of an LED lamp to replace a kerosene lamp, for example, has a positive spillover effect on the health of the users (kerosene vapor is harmful) and the reduction of health and energy costs. A plot of the dimensions mentioned above then yields four types: Market Hybrids, Blending Hybrids, Bridging Hybrids and Coupling Hybrids. Specific challenges and required management strategies are identified on the basis of typologies [32,34]. For example, a key design challenge for the Bridging Hybrids organizations of Santos et al. [32] is to establish appropriate rules to ensure that beneficiaries are properly served, as there is a risk that customers will be given priority over beneficiaries. The board plays an important role in this, but it also includes stimulating processes at the organizational level (such as focus groups and advisory councils) and setting up the organizational structure.

To sum, configurations of key components of the business model of a social enterprise can be referred to as a certain typology. It can be concluded from the literature study that there is no single configuration for social enterprises. Specific challenges and necessary management strategies are identified on the basis of typologies [32,34].

Proposition 4: The business model of a social enterprise is configured as Market Hybrids, Blending Hybrids, Bridging Hybrids and Coupling Hybrids Santos et al. [32].

A social enterprise realizes two apparently separate organizational goals; social value creation and economic value creation $[27,31]$. The aim of this study is to gain more insight into the key components of the business model of social enterprises and how they contribute to the creation of social and economic value. Four propositions have been distilled from the scientific literature. These propositions were investigated in this study via a multiple case study. 


\section{Methodology}

\subsection{Research Method}

This research is an explanatory study with the aim of gaining in-depth and integral insight into the research topic $[34,38]$. The chosen method is a qualitative research method by means of a multiple case study research in which the unit of the analysis is the social enterprise [58,59]. Case study research is a research method in which a phenomenon ("a case") is examined in-depth and in its own context [59].

\subsection{Case Selection}

Six cases were examined for the purpose of the study. Multiple cases were selected because if two or more cases support the same theory, it reinforces the claim of literal and theoretical replication. The research results become stronger if multiple cases support the same theory and can eliminate competing theories [54]. The cases were selected from a long list of initiatives in the Netherlands that meet the definition of a social enterprise [54]. The number of social enterprises in the Netherlands is growing and an increasing percentage of these enterprises make a profit. Furthermore, the Netherlands is one of the front runners in terms of sustainability and inclusion with the ambition to foster a business environment prone to social entrepreneurship [50]. This makes the Netherlands an interesting and relevant research setting for the study of social enterprises. The enterprises in the Netherlands focus on one or more impact areas [18]. As a member of the EU, the Netherlands also stimulates social entrepreneurship. This growth, diversity of focus and positive attitude against social enterprises makes the Netherlands a suitable geographical area to select cases. In making the final selection, predefined criteria were taken into account, taking into account a balanced spread with regard to the mission and region. The following cases were selected.

Case 1. SpringerUit Foundation-Schoorl

The SpringerUit Foundation originated from the daily practice of a printing company: SpringerUit Drukwerk. The foundation was established in 2017. The printing company is 18 years old. Since the start in 2002, the owners of SpringerUit Drukwerk have worked closely with Scorlewald, a care institution for people with intellectual and multiple disabilities. The printing company is located as an independent company on the Scorlewald site in Schoorl. The care side of the printing business was developed in recent years, partly due to the establishment of the SpringerUit Foundation. The foundation wants to offer people with intellectual and multiple disabilities a meaningful daytime activity by treating everyone as an equal and encouraging people to show their talents, at their own level.

\section{Case 2. U-Stable-Utrecht}

U-Stal creates work for people who do not easily find work in other places, such as benefit claimants, the homeless and mental health clients. U-Stal is active within various business units: U-Stal (bicycle shed) and U-Stal Werken (cleaning work). The foundation consists of a supervisory board, the board of directors, the management team and about 150 employees, more than $90 \%$ of whom are on payroll. The other $10 \%$ concerns people who are sometimes seconded from Employment Centers companies or people who have been placed in a work experience or apprenticeship position. The foundation also has a number of private companies as operating companies.

Case 3. Driekant BV-Zutphen

Driekant Ambachtscentrum - an organic bakery with a shop, a lunch café and a bread café-was founded in 1996 by entrepreneur Henk Smit with the aim of creating a society in which everyone can participate according to their own ability. The learning activities are secured in Stichting Driekant Inspireert (SDI). Driekant stands for a working environment in which everyone can participate. Through the pillars of production, education and art, people can develop individually and at the same time be of value to society.

Case 4 IT Vitae-Amersfoort

Social entrepreneurs Frans de Bie and Peter van Hofweegen founded ITvitae seven years ago with the aim of bringing ICT talents with high-functioning autism and/or 
gifted people to a paid and sustainable job. ITvitae consists of the three core activities: Learning, Coaching and Secondment. As of 1 September 2021, ITvitae has placed a total of 400 students and lateral entrants into employment. The social impact: the candidates have the prospect of sustainable participation in the labor process-a fully-fledged place in society-and the clients receive well-trained and motivated professionals in return.

Case 5 MCS Foundation For Life-Eindhoven

MCS Foundation For Life was founded in 2017 by Daniel Stanciu. The purpose of this foundation is to help extend and improve the lives of advanced cancer patients. This is accomplished by: (1) identifying the most promising academics findings that can be fast translated to clinical space (e.g., repurpose drugs); (2) by identifying clinical settings and teams in which these academic discoveries can be implemented; (3) facilitating the connection between the academic teams and the clinical teams with the goal to initiate clinical trials. In addition to the foundation, the concept includes a supplement company (MCS Formulas) and a website (blog) Cancer Treatments Research. The purpose of this blog is to create awareness about new treatment options to increase the effectiveness of conventional methods and to introduce new treatment methods based on scientific evidence.

Case 6 Silvia Ardila Love by Grace

Silvia Ardila Love by Grace is a brand that combines fashion and social impact through craftsmanship. The company is committed to the United Nations' Sustainable Development Goals: poverty reduction, gender equality, decent work and economic growth, and responsible consumption and production. The brand was founded in 2019 by Silvia Ardila.

\subsection{Data Collection}

In order to increase the construct validity, various data sources were also examined according to the "triangulation principle" [59]. In this case study, we studied internal and external resources, such as available company information, company reports and documents, as well as company news articles, press releases, advertisements, website and social media. Due to the exploratory nature of the research, semi-structured interviews were chosen. We conducted 12 personal interviews of approximately $1-1.5 \mathrm{~h}$ on location for each case with the director and $\mathrm{CEO}$ of each organization. The interviewees were given the opportunity to check the interview transcript. To enhance the reliability of the research, the data collection process is described and documented [59]. In order to make the research replicable, an interview protocol was used for the face-to-face interviews.

The reason to carry out personal interviews is that the researcher would like to study a real-life event, gaining to retrieve insights about the propositions laid out in this study, to study the meanings and the relationships between them, and to attain rich, personalized information $[60,61]$. Through personal interviews, next to verbal interaction, the researcher gains a lot of additional information through non-verbal communication, for example, from the tone of voice, intonation, body language, eye contact, supportive gestures, etc. Another advantage is that there is no delay between question and answer, meaning that the answer will be more spontaneous.

The researcher used a semi-structured interview approach containing predetermined questions about the proposition laid out in this study. These predetermined questions increase the completeness of the data and make data collection more systematic for each participant, potential gaps in the process can be anticipated and addressed, and interviews remain conversational and situational [61], together with follow-up questions, which are meant to probe more deeply into the interviewees' responses. This allows the interviewees to express themselves openly and freely from their own perspectives with examples from their own experiences. A disadvantage of holding face-to-face interviews is that the interviewee can direct the interviewer in a special direction, which has nothing to do with the subject of interest. To diminish this effect, the researcher has developed a preliminary interview protocol, which contains all questions the researcher would like to ask the interviewee. 
Through a dry rehearsal of the first version of the interview protocol, the questions did not have a logical order, which resulted in jumping back and forth through subjects related to the propositions. This would surely not contribute to a smooth and structured flow of an actual interview with a start-up, and would also be very difficult for the researcher to track and trace all the interviewee responses correctly and efficiently. To ensure a more smooth and logical flow of an actual interview, and to ensure an effective and efficient analysis later on, the researcher firstly coded each question uniquely per section. Then the researcher ordered each question as such that it represented a logical order building from subject to subject. Having the amended interview protocol helped the researcher to execute the interview in a smoother manner, and has proven an excellent way to structure the interviews across the cases. It also helped the researcher to be less likely to be misled, and being correctly critical in interpreting the contents of all the evidence, thus increasing the reliability of the findings. During the interviews, the researcher had a printed version of the interview protocol to add additional field notes. The same set of questions were asked, in the same order for all cases in this study.

To strengthen the construct validity, several data sources were analyzed (triangulation) and the concepts were operationalized on the basis of empirical data. Pattern matching and cross-case synthesis were applied as an analysis strategy for internal validity.

To enhance the reliability of the research, the data collection process was documented and the same interview protocol was followed throughout all interviews. The fact that a semi-structured questionnaire was used in the face-to-face interviews increases the possibility of replicating the research.

\subsection{Data Analysis}

As an analysis strategy, the deductive approach of Yin [59] was used. This means that theoretical propositions were developed on the basis of the scientific literature and a conceptual framework was established before collecting the data. Inherently, this means that these propositions, the conceptual framework, as well as the research question and objective, are guiding the data collection and analysis. After transcribing and coding, the collected data were analyzed and links were sought on the basis of pattern matching and cross-case analysis [59,62].

\subsection{Operationalization}

The structure of the operationalization was derived from concepts of the research question: social enterprise, social enterprise business model, social and economic value and configuration (Table 1). In addition, concepts were included that were derived from scientific literature and that are relevant for the execution of the research.

Table 1. Operationalization.

\begin{tabular}{|c|c|c|c|}
\hline Concept & Definition & Indicators & Source \\
\hline Social enterprise & $\begin{array}{l}\text { A social entreprise [18] } \\
\text { The primary impact is related to a } \\
\text { social mission; } \\
\text { - The impact is created } \\
\text { through an independent } \\
\text { enterprise that delivers a } \\
\text { service or a product; } \\
\text { - Has a business model; } \\
\text { - } \quad \text { Profit is a resource, not a } \\
\text { goal; } \\
\text { - is transparent and fair to } \\
\text { everyone; } \\
\text { is social in the way the } \\
\text { enterprise is organized; } \\
\text { board and policies are } \\
\text { balanced towards all } \\
\text { stakeholders. }\end{array}$ & $\begin{array}{l}\text { - Facets related to the } \\
\text { definition; } \\
\text { The mission can be } \\
\text { characterized based on: } \\
\text { labor participation, welfare, } \\
\text { environment or } \\
\text { international development } \\
\text { [63]; } \\
\text { - Has a business model; } \\
\text { Exists longer than a year. }\end{array}$ & Social Enterprise [18] \\
\hline
\end{tabular}


Table 1. Cont.

\begin{tabular}{|c|c|c|c|}
\hline Concept & Definition & Indicators & Source \\
\hline Age & Length of existence & $\begin{array}{l}\text { - Age is based on the date of } \\
\text { registration at the Chamber } \\
\text { of Commerce }\end{array}$ & - \\
\hline Typology & $\begin{array}{l}\text { Classification of the social } \\
\text { enterprise into one or two criteria } \\
\text { [54]. }\end{array}$ & $\begin{array}{l}\text { - } \\
\text { Scope of ambition of the } \\
\text { mission; } \\
\text { Impact area; } \\
\text { - } \quad \text { Typology Mair et al. [46]: } \\
\text { political, human, economic } \\
\text { and social; } \\
\text { Typology Santos et al. } \\
\text { [32].market hybrids, } \\
\text { blending hybrids, bridging } \\
\text { hybrids and coupling } \\
\text { hybrids }\end{array}$ & $\begin{array}{c}\text { M. Hogenstijn [29], Social } \\
\text { Enterprise [18,34] } \\
\text { Mair, Battilana, and Cardenas [46] } \\
\text { Santos et al., Santos, Pache [32] }\end{array}$ \\
\hline Business model social enterprise & $\begin{array}{l}\text { The way of doing business in a } \\
\text { holistic way and it explains the } \\
\text { way value is created and } \\
\text { maintained. }\end{array}$ & $\begin{array}{ll}- & \text { Mission; } \\
- & \text { Internal architecture; } \\
\text { - } & \text { Market; } \\
\text { - } & \text { Financial management. }\end{array}$ & Zott et al. [2]. \\
\hline Economic value & $\begin{array}{l}\text { The financial profit for the } \\
\text { shareholders or owners of the } \\
\text { enterprise [32]. }\end{array}$ & - $\quad$ Profit & Santos et al. [32]. \\
\hline Sociale waarde & $\begin{array}{l}\text { the value created by the } \\
\text { organization for society in the } \\
\text { achievement of its mission [32]. }\end{array}$ & - $\quad$ Social value & Santos et al., Santos, Pache [32]. \\
\hline
\end{tabular}

\section{Results}

\subsection{Key Components of the Business Model of Social Enterprises}

The first two propositions involve the key components of a business model of social enterprises. To investigate whether these propositions are confirmed in this dataset we described the key components found in the six cases. Our findings are summarized in Table 2. We investigated the key components of the business model of a social enterprise, namely the mission, the internal architecture, the financial management and the market.

\subsubsection{Key Component: Mission}

Within the key component "mission" several sub components were analyzed. These were the "mission", "scope of the mission", "strategy choices".

From the data, we found that in all six cases, the key component "mission" was important. These social enterprises created a multidimensional impact.

"U-stal offers employment to people who are less able to find a job elsewhere, for example people on social assistance benefit, a Wajong benefit, former homeless people or mental health care clients. They may or may not work in a subsidized job or with a personal budget. It is important that employees are able to develop within their employment." (quote, U-Stal)

Table 2. Characteristics cases.

\begin{tabular}{|c|c|c|c|c|c|c|}
\hline Case & Legal Structure & Mission & Mission Scope & Impact Areas & $\begin{array}{l}\text { Key Activities } \\
\text { Commercial }\end{array}$ & $\begin{array}{l}\text { Key Activities } \\
\text { Social }\end{array}$ \\
\hline ITvitae & $\begin{array}{c}\text { Foundation }+ \\
\text { private company } \\
\text { (Ltd.) }\end{array}$ & $\begin{array}{c}\text { Guiding ICT } \\
\text { specialists with } \\
\text { high-functioning } \\
\text { autism and/or } \\
\text { gifted individuals } \\
\text { to a paid and } \\
\text { sustainable job }\end{array}$ & National & $\begin{array}{c}\text { Labor } \\
\text { participation; } \\
\text { Social cohesion }\end{array}$ & $\begin{array}{l}\text { Secondment/ } \\
\text { employment }\end{array}$ & $\begin{array}{l}\text { Education; } \\
\text { reintegration and } \\
\text { coaching on the } \\
\text { job }\end{array}$ \\
\hline
\end{tabular}


Table 2. Cont

\begin{tabular}{|c|c|c|c|c|c|c|}
\hline Case & Legal Structure & Mission & Mission Scope & Impact Areas & $\begin{array}{l}\text { Key Activities } \\
\text { Commercial }\end{array}$ & $\begin{array}{l}\text { Key Activities } \\
\text { Social }\end{array}$ \\
\hline Springeruit & $\begin{array}{c}\text { Foundation }+ \\
\text { private company } \\
\text { (Ltd.) }\end{array}$ & $\begin{array}{c}\text { Providing } \\
\text { meaningful } \\
\text { daytime activities } \\
\text { for people with } \\
\text { intellectual and } \\
\text { multiple } \\
\text { disabilities' }\end{array}$ & Local/regional & $\begin{array}{c}\text { Labor } \\
\text { participation; } \\
\text { Social cohesion }\end{array}$ & Printing house & $\begin{array}{l}\text { Daytime } \\
\text { care/learning } \\
\text { trajectory }\end{array}$ \\
\hline Driekant & $\begin{array}{l}\text { Foundation }+ \\
\text { private company } \\
\text { (Ltd.) }\end{array}$ & $\begin{array}{l}\text { Realizing a } \\
\text { society where } \\
\text { everyone can } \\
\text { participate in the } \\
\text { economic process } \\
\text { according to their } \\
\text { own ability }\end{array}$ & Local/regional & $\begin{array}{c}\text { Labor } \\
\text { participation; } \\
\text { Social cohesion; } \\
\text { Sustainability }\end{array}$ & $\begin{array}{l}\text { Bakery and } \\
\text { lunchroom }\end{array}$ & $\begin{array}{c}\text { Personal } \\
\text { development } \\
\text { (production, } \\
\text { formation, art) }\end{array}$ \\
\hline U-Stal & $\begin{array}{l}\text { Foundation }+ \\
\text { private company } \\
\text { (Ltd.) }\end{array}$ & $\begin{array}{c}\text { Offering } \\
\text { employment to } \\
\text { people who are } \\
\text { less able to find } \\
\text { work elsewhere } \\
\quad \text { elders }\end{array}$ & Local/regional & $\begin{array}{c}\text { Labor } \\
\text { participation; } \\
\text { Social cohesion }\end{array}$ & Facility services & $\begin{array}{l}\text { Education and } \\
\text { coaching on the } \\
\text { job }\end{array}$ \\
\hline $\begin{array}{l}\text { MCS Foundation } \\
\text { For Life }\end{array}$ & $\begin{array}{c}\text { Foundation }+ \\
\text { private company } \\
\text { (Ltd.) }\end{array}$ & $\begin{array}{c}\text { Extend and } \\
\text { improve the lives } \\
\text { of cancer patients }\end{array}$ & Global & $\begin{array}{l}\text { Health; Social } \\
\text { cohesion }\end{array}$ & - & $\begin{array}{l}\text { Knowledge } \\
\text { sharing about } \\
\text { treatments }\end{array}$ \\
\hline $\begin{array}{c}\text { Silvia Ardila Love } \\
\text { by Grace }\end{array}$ & proprietorship & $\begin{array}{l}\text { Improving the } \\
\text { lives of everyone } \\
\text { involved through } \\
\text { the sale of } \\
\text { handmade } \\
\text { products. }\end{array}$ & Global & $\begin{array}{l}\text { International } \\
\text { development; } \\
\text { poverty } \\
\text { reduction; gender } \\
\text { equality, cultural } \\
\text { preservation; } \\
\text { sustainability }\end{array}$ & $\begin{array}{l}\text { Online sales } \\
\text { sustainable } \\
\text { products }\end{array}$ & $\begin{array}{l}\text { Initiation projects } \\
\text { in region of target } \\
\text { group }\end{array}$ \\
\hline ITvitae & $\begin{array}{c}\text { Foundation }+ \\
\text { private company } \\
\text { (Ltd.) }\end{array}$ & $\begin{array}{c}\text { Guiding ICT } \\
\text { specialists with } \\
\text { high-functioning } \\
\text { autism and/or } \\
\text { gifted individuals } \\
\text { to a paid and } \\
\text { sustainable job }\end{array}$ & National & $\begin{array}{c}\text { Labor } \\
\text { participation; } \\
\text { Social cohesion }\end{array}$ & $\begin{array}{l}\text { Secondment } \\
\text { /employment }\end{array}$ & $\begin{array}{l}\text { Education; } \\
\text { reintegration and } \\
\text { coaching on the } \\
\text { job }\end{array}$ \\
\hline Springeruit & $\begin{array}{c}\text { Foundation }+ \\
\text { private company } \\
\text { (Ltd.) }\end{array}$ & $\begin{array}{c}\text { Providing } \\
\text { meaningful } \\
\text { daytime activities } \\
\text { for people with } \\
\text { intellectual and } \\
\text { multiple } \\
\text { disabilities' }\end{array}$ & Local/regional & $\begin{array}{c}\text { Labor } \\
\text { participation; } \\
\text { Social cohesion }\end{array}$ & Printing house & $\begin{array}{l}\text { Daytime } \\
\text { care/learning } \\
\text { trajectory }\end{array}$ \\
\hline Driekant & $\begin{array}{c}\text { Foundation }+ \\
\text { private company } \\
\text { (Ltd.) }\end{array}$ & $\begin{array}{l}\text { Realizing a } \\
\text { society where } \\
\text { everyone can } \\
\text { participate in the } \\
\text { economic process } \\
\text { according to their } \\
\text { own ability }\end{array}$ & Local/regional & $\begin{array}{l}\text { Labor } \\
\text { participation; } \\
\text { Social cohesion; } \\
\text { Sustainability }\end{array}$ & $\begin{array}{l}\text { Bakery and } \\
\text { lunchroom }\end{array}$ & $\begin{array}{c}\text { Personal } \\
\text { development } \\
\text { (production, } \\
\text { formation, art) }\end{array}$ \\
\hline U-Stal & $\begin{array}{c}\text { Foundation }+ \\
\text { private company } \\
\text { (Ltd.) }\end{array}$ & $\begin{array}{c}\text { Offering } \\
\text { employment to } \\
\text { people who are } \\
\text { less able to find } \\
\text { work elsewhere } \\
\text { elders }\end{array}$ & Local/regional & $\begin{array}{c}\text { Labor } \\
\text { participation; } \\
\text { Social cohesion }\end{array}$ & Facility services & $\begin{array}{l}\text { Education and } \\
\text { coaching on the } \\
\text { job }\end{array}$ \\
\hline
\end{tabular}


Table 2. Cont.

\begin{tabular}{|c|c|c|c|c|c|c|}
\hline Case & Legal Structure & Mission & Mission Scope & Impact Areas & $\begin{array}{l}\text { Key Activities } \\
\text { Commercial }\end{array}$ & $\begin{array}{l}\text { Key Activities } \\
\text { Social }\end{array}$ \\
\hline $\begin{array}{l}\text { MCS Foundation } \\
\text { For Life }\end{array}$ & $\begin{array}{c}\text { Foundation }+ \\
\text { private company } \\
\text { (Ltd.) }\end{array}$ & $\begin{array}{c}\text { Extend and } \\
\text { improve the lives } \\
\text { of cancer patients }\end{array}$ & Global & $\begin{array}{l}\text { Health; Social } \\
\text { cohesion }\end{array}$ & - & $\begin{array}{c}\text { Knowledge } \\
\text { sharing about } \\
\text { treatments }\end{array}$ \\
\hline $\begin{array}{l}\text { Silvia Ardila Love } \\
\text { by Grace }\end{array}$ & proprietorship & $\begin{array}{l}\text { Improving the } \\
\text { lives of everyone } \\
\text { involved through } \\
\text { the sale of } \\
\text { handmade } \\
\text { products. }\end{array}$ & Global & $\begin{array}{l}\text { International } \\
\text { development; } \\
\text { poverty } \\
\text { reduction; gender } \\
\text { equality, cultural } \\
\text { preservation; } \\
\text { sustainability }\end{array}$ & $\begin{array}{l}\text { Online sales } \\
\text { sustainable } \\
\text { products }\end{array}$ & $\begin{array}{c}\text { Initiation projects } \\
\text { in region of target } \\
\text { group }\end{array}$ \\
\hline
\end{tabular}

One case (Driekant) created an impact on labor participation by offering people at a distance to the labor market with a learning trajectory. They also incorporated sustainability in their mission by making sure that all purchases are $100 \%$ biological. They thus focused on two impact areas at the same time. Another example was the case of the MCS Foundation for life. They created a primary impact on the health of the people by prolonging and improving the lives of cancer patients, and created impact via the creating of communities (e.g., a blog that improves social cohesion amongst these cancer patients, families, academics and medici. Silvia Ardila Love by Grace created an impact by focusing on poverty reduction, gender equality, economic growth, welfare of the target group and sustainability:

“... In line with the activities, Silvia Ardila Love by Grace focuses on non-poverty, gender equality, decent work and economic growth and responsible consumption and production .... We work only on collections. With this we try not to have overproduction, being conscious and respectful with the environment." (quote, Silvia Ardila Love by Grace)

The scope of the missions of the respondents varies on different levels of ambition. They vary from local, national and international. This does not appear to be related to a specific impact area. The scope is mostly confined due to the nature of the work and regulations of the local government. Specific healthcare resources and subsidies are coupled with specific regional areas.

The strategy choices of these social enterprises are related to the mission. The activities of the company serve the realization of the mission. The mission of the SpringerUit Foundation is, for example, to offer meaningful daytime activities for people with intellectual and multiple disabilities. The director of SpringerUit, for example, would rather purchase a semi-automatic printing press that also includes an action than a fully automatic device that the clients do not need to work on as expressed by the following quote:

"So I prefer it to be a lot of manual work. When we buy machines, it is always semiautomatic. There must also be an action, otherwise it will miss its purpose. I can throw paper into something and then: prrrr, it gets folded, but then people don't have a job. So I'd rather they just put it in by hand." (quote: SpringerUit)

\subsubsection{Key Component: Internal Architecture}

Within the key component "internal architecture" several sub components were analyzed. These were the "legal structure", "type of activities", "stimulating resources" and "inhibiting resources".

Most social enterprises (five of the six cases) were foundations with one or more private companies linked to the foundation. Commercial activities were situated within the private company and serve as a way to make purchases. The social activities, such as education, apprenticeship programs and health care were operated via the foundation. 
"Our foundation does not have a profit motive, but we use the foundation for training activities." (quote ITvitae)

The foundation is also the way for these enterprises to receive subsidies and/or donations. One case differed from the other five cases in that it was a proprietorship. This difference might be related to the initial costs to set up a business. This case has the ambition to create a foundation in the future. It seems that at least for these entrepreneurs, the legal structure is an important component of the business model. In terms of form, the combination of foundation with a private company is mainly chosen. According to the research results, this choice is not specifically related to the impact area of the company. The division of legal structure (foundation vs private company) is also reflected in the activities of the social enterprises.

The commercial activities (e.g., ICT, software development, printing, bakery and catering, facility services, and sales) vary for each enterprise. The social activities were in line with the mission. Four of the six cases were focused on labor participation and personal development. Examples are: folding papers, sorting (SpringerUit), production of bread and catering (Driekant), apprenticeship programs related to bicycle sheds (UStal). A characteristic of the cases is that the employees and clients-the target group-are part of the social enterprise and carry out activities for the benefit of the commercial activities. This is not the case for MCS Foundation For Life and Silvia Ardila Love by Grace. MCS Foundation For Life opens up scientific research for cancer patients with the aim of developing new treatment methods and that Silvia Ardila acts as an intermediary for producers and makes a (new) sales market accessible.

All six cases use different resources to reach their target group. Some resources accelerate the development of the business model and others inhibit the development. An overview of the resources is given in Table 3. They use websites, a network and marketing. Positioning and brand awareness are important resources, because customers choose, whether or not because of their CSR policy, to award contracts to these companies or to purchase a product or service. These resources can be qualified as more generic because they are used by all companies. The extent to which they are used, however, may differ per company. Based on the interviews, the website seems to have a more prominent place in the business model for MCS Foundation For Life and Silvia Ardila Love by Grace than for the other social enterprises.

Table 3. Stimulating and inhibiting resources.

\begin{tabular}{lll}
\hline Stimulating Resources & \# Times Mentioned \\
\hline & Drive and personal believes & 6 \\
\hline Quality of product or services & 5 \\
\hline $\begin{array}{l}\text { Contribution of other companies } \\
\text { (via CSR policy) }\end{array}$ & 3 \\
\hline Employees/clients & 3 \\
\hline Trust & 2 \\
\hline Expertise & 2 \\
\hline Expansion via internet & 1 \\
\hline PR & 1 \\
\hline Love & 1 \\
\hline Abolition of laws & 1 \\
\hline Network & 1 \\
\hline
\end{tabular}


Table 3. Cont.

\begin{tabular}{lll}
\hline Stimulating Resources & \# Times Mentioned \\
\hline & Lack support local government & 2 \\
\hline Extra regulations healthcare & 2 \\
\hline Regulations labor participation & 2 \\
\hline Lack of time & 2 \\
\hline $\begin{array}{l}\text { Diverse ways of working of } \\
\text { municipalities }\end{array}$ & 2 \\
\hline $\begin{array}{l}\text { No culture of giving in The } \\
\text { Netherlands }\end{array}$ & 1 \\
\hline Legal obligations as an employer & 1 \\
\hline Healthcare cuts & 1 \\
\hline No focus on strategy & 1 \\
\hline Lack of trust in market & 1 \\
\hline
\end{tabular}

"Our blog has grown to more than half a million visitors a year. International mainly. The blog is clearly for us a key component through which the stakeholders constantly stay connected with doctors. It also serves as a means of exposure for the different stakeholder groups and interest awareness and network of connections." (quote, MCS Foundation For Life)

There are also resources that are more mission-specific. For example, ITvitae, Driekant, Stichting SpringerUit and U-Stal use training and guidance as part of the business model, the other two social enterprises do not. Other resources are: quality of the product, and expertise and the employees themselves. The respondents mention that these resources, together with the drive and personal believes are important and that it accelerates the development in relation to the business model.

When discussing the inhibiting resources the respondents mentioned several resources. These resources were mostly external resources, such as law and regulations, lack of support from the local governments and different approaches of the local governments (see Table 3). This is illustrated by a quote from Driekant:

“... That was a problem we ran into. Previously, all care was national. Everyone from the entire environment or region, if you had that indication or the right tick, you could come and work here or do a trajectory. At some point this was regulated by municipalities and municipalities made their own conditions and their own forms."

However, the lack of financial resources is the main inhibiting factor.

"Yes, I actually want to expand. Only I am now looking for funds to realize that." (quote: SpringerUit)

\subsubsection{Key Component: Market}

Within the key component "market" several sub components were analyzed. These were the "target group", "customer population" and the "network".

The target group of four out of six companies was people with a distance from the labor market. ITvitae focuses on ICT talents with high-functioning autism and/or gifted individuals. The SpringerUit Foundation is committed to people with intellectual and multiple disabilities. Driekant offers development opportunities to people with very diverse backgrounds, including people with autism but also with a physical, mental or sensory disability, burnout, the long-term unemployed, and people who are integrating back into the labor market. U-Stal has a similar target group. The MCS Foundation For Life focuses on cancer patients and their families, academics and medical world. Silvia Ardila Love by Grace is committed to the Wayuu indigenous group of Colombia's Guajira Peninsula and northwestern Venezuela. The target group is linked to the mission of the case company. 
The customer population of the six case companies interviewed is mixed and is related to the products and services that the company produces. Three cases are working with organizations related to their core activity (ITvitae-ICT professionals; SpringerUit-printing houses; Driekant-bakeries). U-stal needs to collaborate with local governments, MSC Foundations for Life works with patients and Silvia Ardila Love by Grace has customers that have some affinity with sustainable products.

We can divide the network of the social enterprises into three categories. One category is the business partners of the social enterprises. The goal of this network is to acquire assignments and generate income. For example, ITvitae keeps in contact with a pool of potential clients. These clients can give students work after their studies. Another category of the network is the peer network. This comprises equal-minded entrepreneurs or organizations that are active within the same work field. The goal of this network is to share knowledge and expertise. All six cases emphasized the importance of having both types of networks. A third network is based on the collective creation of social value. The activities can be incidental or structural. Examples of incidental activities are: the organization of the theme congress together with partners within the branch (ITvitae) or organizing experience days together with other organizations (Driekant). Three cases mention more structural network activities. For example, Driekant has created the "Learn Guarantee Plan". The aim of this plan is to generate funds together with private individuals, family, companies and incentive funds so that Driekant can secure the employment training for the coming years.

"We have different networks. We have an autism network. They know us and we also show ourselves. That's one network. We have a network of other social enterprises that you work with. This network can consist of various social enterprises. Some look like us, but they have a different target group." (quote, ITvitae)

Silvia Ardila works with partners to provide electricity to communities in Guajira through solar panels. And MCS Foundation for Life is in constant contact with medical specialists and universities for both his blog and foundation with the aim of gathering knowledge about treatments and making this knowledge and treatments available to cancer patients.

\subsubsection{Key Component: Financial Management}

The costs of the social enterprises are either related to the internal organization (e.g., rent and insurance) or costs related to their social mission (e.g., training or financing social projects). The revenues are related to commercial activities, subsidies and donations. However, five of the six entrepreneurs mentioned that creating profit is not the primary goal of the social enterprise. These entrepreneurs intentionally manage the profit to the benefit of the social mission. At ITvitae, for example, it is statutory that $50 \%$ of the profit flows back to the foundation, earning is secondary to the company. Money is not the primary goal for Silvia Ardila either. They donate 50\% of the profit to invest in social projects. In the future, MCS Formulas will invest 51\% of its profits in MCS Foundation For Life and other related causes.

"Whenever an investor joins, they have to agree on this condition: 51 percent will be invested in MCS Foundation for Life. We also have a third party auditing company to make sure that we do that." (quote, MCS Foundation)

Entrepreneur Hans Springer (SpringerUit) knowingly started a new social printing business eighteen years ago-after he sold his printing business. Driekant invests a percentage of its turnover in the Learning Plan. In addition, Driekant places the realization of a good organic product with as much attention as possible for the people involved first, meaning that the profit margin is reduced as a result. 


\subsubsection{Coherence between Key Components}

The respondents discuss key and sub-components in conjunction with each other. For example, according to the interviews, social entrepreneurs make strategic choices with regard to all components of the business model. These choices related to key or sub-components can often be related to the mission. Key and sub-components are also interrelated (Table 4). As an example, one respondent mentioned the interrelatedness between structure and activities:

Table 4. Examples of coherence between key components.

\begin{tabular}{ll}
\hline Case & Example \\
\hline ITvitae & $\begin{array}{l}\text { Coherence between structure and activities } \\
\text { "And if you are going to develop new activities, for example ITvitae housing, it goes } \\
\text { through the board." }\end{array}$ \\
\hline ST. SpringerUit & $\begin{array}{l}\text { Coherence between customer, ambassador and target group. } \\
\text { Look, if you just look around, I have fifteen representatives. These are just my } \\
\text { representatives. When a customer comes in, they are sold." }\end{array}$ \\
\hline Driekant & $\begin{array}{l}\text { Coherence between network and activities } \\
\text { "Yes, and we sometimes look for internships outside the company, in other companies. To } \\
\text { make that step a little smaller, maybe to a regular place." }\end{array}$ \\
\hline U-Stal & $\begin{array}{l}\text { Coherence between network and employees } \\
\text { "That you link employees with another employer based on the vacancy. We have already } \\
\text { had some initial conversations about that." }\end{array}$ \\
\hline MCS Foundation For Life & Coherence between network, resources and target group. \\
& "The blog has been visited by half a million unique visitors in the past three years. The site \\
is a meeting point for patients, scientists and clinicians."
\end{tabular}

"And if you are going to develop new activities, for example ITvitae housing, it goes through the board." (quote ITvitae)

\subsection{Social and Economic Value}

The third proposition is related to the value that these social enterprises create. From the data, we can conclude that the cases realize income through the commercially used revenue model on the one hand and secondary income on the other. Realizing the highest possible profit is not a goal in itself, but generating income serves the continuity of the company. After all, there is no future without a healthy financial household. For a number of social enterprises, the commercial revenue model is not yet sufficiently provisional and the enterprise must also partly rely on additional income, subsidies or donations and unpaid work (volunteer work). The social enterprises create social and economic value through the mutually interacting functioning of the mission, internal architecture, market and financial management. The components are not separate from each other.

To illustrate, Driekant, U-Stal, ITvitae and SpringerUit realize social value by reducing people's distance from the labor market, by offering training and development programs on the one hand and work experience in the company on the other. As a result, people either find a pleasant daytime activity or gain experience with it, which increases their chances of finding a job.

"Driekant is a bakery that bakes bread, bakes cookies. Actually it has a whole bakery assortment, all organic raw materials/products. So there is a bit of sustainability in that. But Driekant is mainly a place where people can all participate and can also fully participate in a commercial setting. So not a social workplace, but a commercially driven workplace. So we try to consider it as real work." (quote, Driekant) 
The entrepreneurs of these case companies emphasize that "participating" and "developing" contribute positively to general well-being. MCS Foundation For Life is committed to extending and improving the lives of cancer patients. Silvia Ardila Love by Grace is committed to preserving Latin American culture and positively advancing lives, especially those of the indigenous Wayuu women and children in Colombia.

\subsection{Configuration of Business Models of Social Enterprises}

The fourth proposition was related to the configuration of the social enterprises. When analyzing the data we found that the companies can be characterized according to impact area and scope of social ambition (local versus national versus global). However, the scope of a social enterprise's social ambition is not related to a specific impact area.

The social enterprises are characterized by a primary and secondary impact area. In our cases, the primary impact area was mostly related to labor participation. This was mostly accompanied by the additional impact area 'social cohesion' and/or 'sustainability'. The other primary impact area was health and international development, poverty reduction, gender equality and cultural preservation. Based on the findings, the companies have also been classified according to the typologies of Santos et al. [32], see Table 5. When classifying these cases according to Santos et al. [32], we find the following classification. Most cases can be categorized as a bridging hybrid, while one case is categorized as a market hybrid.

Table 5. Overview cases according to the configuration.

\begin{tabular}{llll}
\hline & Primary Impact Area & Additional Impact Areas & Configuration [32] \\
\hline ITvitae & Labor participation & Social cohesion & Bridging hybrid \\
\hline SpringerUit & Labor participation & Social cohesion & Bridging hybrid \\
\hline Driekant & Labor participation & Social cohesion; sustainability & Bridging hybrid \\
\hline U-Stal & Labor participation & Social cohesion & Bridging hybrid \\
\hline MSC Foundation for Life & Health & Social cohesion & Market hybrid \\
\hline \multirow{2}{*}{ Silvia Ardila Love by Grace } & $\begin{array}{l}\text { International development; } \\
\text { poverty reduction; gender } \\
\text { equality, cultural preservation }\end{array}$ & sustainability & Bridging hybrid \\
\hline
\end{tabular}

\section{Conclusions and Discussion}

This section sequentially discusses results, the scientific and practical relevance, the limitations of the research and the recommendations. This research aimed to provide more insight into the characteristic components of business models of social entrepreneurs. The main research question was as follows: How do key components of the business model of social enterprises contribute to the creation of social and economic value?

\subsection{Discussion Key Components}

The cases in this research create social and economic value through the mutually interacting operation of key components and their sub-components. This interacting effect focuses on the one hand on the alignment of the internal architecture, market and financial management with the mission. However, the first three key components and sub-components also interact with each other. For example, the type of customer is related to the type of activities (the products and/or services that the company provides). The key components of the business model are in coherence with each other. The mission statement serves as a guiding principle, according to the choices made by the interviewees with regard to, for example, the organization of the legal structure or the choice of the deployment of resources and activities.

Despite the general increase in the literature on business models, researchers do not agree on what a business model is [2]. It is generally agreed that a business model 
explains the way of doing business in a holistic way of both value creation and retention [2]. This holistic approach is reflected in the research results: the collaborative whole and the interacting functioning of the mission, internal architecture, market and financial management create social and economic value. There is no clear picture of which key components are part of the business model [14]. In conjunction with the aim of the present study and taking into account the specificity of social business models and the scientific literature $[15,44,46,64]$, the following key characteristic components of the business model of a social enterprise for the research model are identified: the mission, the internal architecture, the financial management and the market. These key components are further characterized by several sub-components, which have been determined on the basis of the analysis of the research results. The main classification of the key components has proved to be effective during the study. It stands out that five out of six social entrepreneurs mentioned the legal structure as the first aspect of the business model. However, the mission, resources, (network) partners, activities and target audience are also important sub-components of the business model. Based on the results, it is recommended to broaden the perspective of the market. Besides the components of "target group", "customers" and "network", we also need to take external stakeholder (such as national and local government) into account, because legislation and regulations can be both a stimulating and a hindering obstacle for companies. Previous research on social enterprises and hybrid organizations emphasized the importance of multi-stakeholder governance and the collective action/networking for stable organizations but also to scale $[9,27,51]$. The results of this study showed that it is indeed important to involve all these stakeholders in the process to create impact. The research results therefore largely support proposition 1 : the mission, the internal architecture, the financial management and the market are key components of the business model of a social enterprise.

The present study also shows that the mission works as a guiding principle for subcomponents such as the legal structure, target audience, customers, network partners, resources and activities. This confirms the importance of the mission in social enterprises. It serves as a guiding mechanism that balances the social aspect and the financial aspect. Without the guidance of the mission, there is the risk of mission drift, in which which the organization might drift away from its initial mission and the balance between social impact and profit is lost and the core defining characteristics of a social enterprise is at risk [48]. Thus, maintaining the balance is crucial. Support is also found for the research of Qasharin [44] in which she suggests adding the mission, acting as a guideline for the enterprise, as an additional "building block" to the BMC to understand how a social enterprise creates, delivers and retains social value. This means that our research results also provide support for proposition 2: The mission of a social enterprise provides direction for the way in which other key components are implemented.

\subsection{Discussion Social and Economic Value}

An enterprise has a specific goal and produces the effect in the form of value creation. For social enterprises, this effect includes social and economic value $[9,25,27,39]$. Based on the results we can conclude, that realizing the highest possible profit is not a goal in itself for social entrepreneurs, generating income serves the continuity of the company and the realization of social value. However, without a healthy financial household, there is no future. During the interview, five social entrepreneurs indicated that realizing profit is not the primary goal of the company. These entrepreneurs consciously impose "rules of the game" on themselves with regard to profits for the benefit of the social mission. These results support the group of scientific authors on definition issues surrounding the term "social enterprise" that associate economic value with social purpose, even though that is not the primary mission $[19,35,65]$.

Jonker et al. [15] distinguish the following elements with regard to the new business models for sustainable companies: (1) A basic logic (the values and principles that parties share with each other), (2) strategic choices that are made, (3) developing and maintaining 
a value network and (4) organizing cooperatively. For Jonker et al. [15], these elementary building blocks constitute mutual value creation and also serve as a barrier to entry into the competition. The present study also looked at the networks and cooperation with partners. The results show that the case companies indeed pursue collaborations that are dominated by the joint creation of social value. However, these specific network activities must be divided into incidental and structural activities. Only three cases reported such network activities of a somewhat more structural nature (but still under construction/development) involving cooperative organization as intended by Jonker et al. [15] and others [9,27,47]. As a result, there is insufficient support from the research results for proposition (3): Social enterprises develop and maintain cross-organizational networks to jointly create social value.

\subsection{Discussion Configuration of Business Models of Social Enterprises}

Based on the results, the case companies were classified on the basis of the existing configuration of Santos et al. [32] and Mair et al. [46]. Based on the findings, it is not possible to classify the companies on the basis of one of the four ideal types of Mair et al. [46] because the case companies are active in more than one impact area. There is recognition in the literature that it is difficult to define the characteristics of a social enterprise and its boundaries [20,34]. Criteria that are used in the scientific literature to characterize social enterprises are, for example: the basis of origin, impact area and scope of the social ambition (local versus national versus global) or a combination of these [29]. Our results show that the companies can be characterized according to these characteristics. The scope of the social ambition of a social enterprise is not related to a specific impact area, combining these characterizations, therefore, leads to a differentiated configuration. The research results show that there are both nationally operating social case companies in the field of labor participation, but also locally/regional operating social case companies. The effect of this differentiation on key components such as resources has not been further investigated in this study.

Mair et al. [46] identify four ideal types based on impact: political, human, economic and social. This characterization does not seem the most fruitful, because the research results show that social enterprises have multiple impacts through the achievement of their mission. In concrete terms, this means that a social enterprise can be designated by more than one of the four ideal types [46].

According to the configuration of Santos et al. [32], the case companies are so-called bridging hybrids. Santos et al. [32] argue that bridging hybrids organizations face specific design challenges because of the risk that customers are prioritized over beneficiaries. The researchers recommend establishing appropriate rules to ensure that beneficiaries are properly served, supervised by a board and the organizational structure adjusted accordingly. ITvitea, Driekant, Stichting SpringerUit and U-Stal do this by, among other things: the legal structure (one or more private limited companies with a foundation next to it), the installation of a board of directors, compliance with the articles of association, and making agreements with related to profit. Silvia Ardila Love by Grace also does the latter. However, this company has a different legal structure (proprietorship). This is perhaps related with the relatively young age of the organization and the costs associated with setting up a private company (Ldt.). According to the configuration Santos et al. [32], MCS Foundation For Life is a market hybrid. This means that the target audience and the customers are the same group. The advantage of this is that the company can concentrate on just one activity; the sale of products or services that have automatic spillover effects. According to Santos et al. [32] market hybrids are therefore helped by a unifunctional organizational structure aimed at these commercial activities. Recruiting employees and partners with operational business expertise should therefore be a priority.

This means, that the research results support proposition 4: The business model of a social enterprise are configured as Market Hybrids, Blending Hybrids, Bridging Hybrids and Coupling Hybrids. 


\subsection{Scientific Contribution}

This research contributes to the creation of a better understanding of the key components of the business model of social enterprises and how they create social and economic value. One of the defining aspects of a social enterprise is that it has a hybrid nature $[25,27,39]$. It strives to create social value and at the same time economic value. This dual nature needs to be reflected in the structure and in the business model components of the organization. Previous research has hinted at the importance of the mission in maintaining the balance between social and economic value $[25,27,39]$. The results of our research support the scientific literature with regard to the statement that the mission of a social enterprise has a guiding effect for the organization and that the mission, together with the internal architecture, the financial management and the market as characteristic key components of the business model of a social enterprise. On the other hand, literature has stated the importance of networking and collective action to scale the activities of the social enterprise $[25,27,39,47]$. In our cases, this was acknowledged but the collective action and the use of multiple stakeholders were not always structural and therefore used to scale the activities. Future research could focus on the way structural and incidental cooperation between the social enterprises helps to create more impact for society.

\subsection{Practical Implications}

Regarding the practical relevance, Phillips et al. [24] argue that the shrinking public sector and pressure on the classic, profitable business model are reasons for the increased interest in social enterprises in recent years. The apparent added value of a social enterprise is seen as an untapped opportunity for commercial organizations. Managers of these companies could therefore in theory learn something from social enterprises. It is also important for social entrepreneurs to better understand what works and what does not. Therefore, configurations were also examined in this study. Configurations of key components of the business model of a social enterprise can be referred to as a certain typology. Specific challenges and business model solutions have been identified based on the typologies of Santos et al. [32]. These findings offer similar social enterprises tools and lessons for developing their own management strategy.

\subsection{Limitations and Future Research}

This research has several limitations. These limitations inspire a few future research areas. The main limitation of the study lies in its generalizability to a population. In this case study, the number of cases studied is too small to be able to make firm statements about the population. However, Yin [59] argues that case study research does not apply the logic of a survey, but the logic of an experiment, namely a replication logic. Case study research is conducted to test whether the findings are consistent with a theory. If this is the case, the theory is supported and more robust: analytic generalization. To make the research gain momentum, cases with different impact areas were selected and then tested against the existing theory. However, precisely because of the different impact areas, the application of replication logic has not been possible in all cases, because research results were available within the primary impact the areas of health and international development of only one case company. Given the small sample size, it is recommended to duplicate the study with a larger sample size, which may increase both the significance and strength of any relationships. The second limitation relates to the deductive method of the study, because pre-specifying the theory may prematurely exclude certain matters to be investigated [66,67]. This was taken into account through the use of semi-structured interviews and the cross-analysis method, which also allowed for non-predefined topics and themes to emerge during the research. A third limitation relates to the scope of the study. The research focused primarily on the 'hard elements' of the business model. During the interview, a few entrepreneurs indicated that the so-called 'soft skills' of the entrepreneurs and other competences that an entrepreneur needs to start a social enterprise, they also felt that they were part of the business model $[53,68]$. Further research 
is needed to see to what extent these skills and competencies can possibly be regarded as a resource, being a sub-component, of the business model. It is also recommended to further investigate the configurations of key components [53,69]. After all, the research results show that there are both nationally operating social case companies in the field of labor participation, but also locally/regional operating social case companies. This raises the question of whether a further refinement or differentiation in the configuration of the key components will lead to variations or completely different typologies, which may be based on yet another management strategy. And finally, the literature puts sustainable business models on the virgin shield for the realization of new technologies and social activities at a time of great need for change. The continuous evolution of these business models brings us step by step closer to a more sustainable world. That in itself is worth investigating $[53,70]$.

\subsection{Concluding Remarks}

The purpose of this study was to investigate how the key components of the business model of social enterprises contribute to the creation of social and economic value. Our study showed several results regarding this relationship. The main conclusions were (a) the key components of the social business model are the mission, internal architecture, market and financial management. We also found that (b) the key component "mission" is the guiding principle. The mission guides the adaptation of the other key components. Furthermore, we conclude that (c) generating profit is not a goal in itself for social entrepreneurs, but it serves the realization of the social value and insures the continuation of the company. Finally, the fourth contribution is $(\mathrm{d})$ the business model of social enterprises can be configured following the typology of Santos et al. [32].

Author Contributions: Conceptualization, E.D. and C.L.V.; methodology, E.D.; software, E.D. and P.C.M.N.; validation, P.C.M.N. and C.L.V. formal analysis, E.D.; investigation, E.D.; resources, E.D.; data curation, E.D. and C.L.V.; writing-original draft preparation, E.D. and P.C.M.N.; writingreview and editing, C.L.V. and P.C.M.N.; visualization, P.C.M.N. and E.D.; supervision, C.L.V.; project administration, C.L.V. All authors have read and agreed to the published version of the manuscript.

Funding: This research received no external funding.

Institutional Review Board Statement: Not applicable.

Informed Consent Statement: Not applicable.

Data Availability Statement: Data scharing not applicable.

Conflicts of Interest: The authors declare no conflict of interest.

\section{References}

1. United Nations. About the Sustainable Development Goals. 2018. Available online: https://sdgs.un.org/ (accessed on 1 June 2021).

2. Zott, C.; Amit, R.; Massa, L. The business model: Recent developments and future research. J. Manag. 2011, 37, $1019-1042$.

3. Lüdeke-Freund, F. Towards a Conceptual Framework of Business Models for Sustainability. In Knowledge Collaboration Learning for Sustainable Innovation, Proceedings of the ERSCP-EMSU Conference, Delft, The Netherlands, 25-29 October 2010; Wever, R., Quist, J., Tukker, A., Woudstra, J., Boons, F., Beute, N., Eds.; Faculty of Industrial Design Engineering, Delft University of Technology: Delft, The Netherlands, 2010; pp. 25-29.

4. Georgieva, K. The Great Reset. Remarks to World Economic Forum, June 2020. Available online: https://www.imf.org/en/ News / Articles/2020/06/03/sp060320-remarks-to-world-economic-forum-the-great-reset (accessed on 1 June 2021).

5. Dentchev, N.; Moingeon, B.; Lehmann-Ortega, L. Embracing the variety of sustainable business models: Social entrepreneurship, corporate intrapreneurship, creativity, innovation, and other approaches to sustainability challenges. J. Clean. Prod. 2016, 113, 1-4. [CrossRef]

6. Rauf, F.; Tap, M.; van Straaten, T. Moderating effect of political embeddedness on the relationship between resources base and quality of CSR disclosure in China. Sustainability 2020, 12, 3323. [CrossRef]

7. Rauf, F.; Dacin, P.A.; Tracey, P. CSR Disclosure: Effects of Political Ties, Executive Turnover and Shareholder Equity. Evidence from China. Sustainability 2021, 13, 3623. [CrossRef]

8. Dart, R. The legitimacy of social enterprise. Nonprofit Manag. Leadersh. 2004, 14, 411-424. [CrossRef]

9. Tortia, E.C.; Degavre, F.; Poledrini, S. Why are social enterprises good candidates for social innovation? Looking for personal and institutional drivers of innovation. Ann. Public Coop. Econ. 2020, 91, 459-477. [CrossRef] 
10. Schaltegger, S.; Lüdeke-Freund, F.; Hansen, E.G. Business models for sustainability: A co-evolutionary analysis of sustainable entrepreneurship, innovation, and transformation. Organ. Environ. 2016, 29, 264-289. [CrossRef]

11. Teece, J.D. Business Models. Bus. Strategy Innov. Long Range Plan. 2010, 43, 2-3.

12. Porter, M.; Kramer, M. Strategy and Society: The Link Between Competitive Advantage and Corporate Social Responsibility. Harv. Bus. Rev. 2006, 48, 78-92.

13. Yunus, M.; Moingeon, B.; Lehmann-Ortega, L. Building social business models: Lessons from the Grameen experience. Long Range Plan. 2010, 43, 308-325. [CrossRef]

14. Michelini, L.; Fiorentino, D. New business models for creating shared value. Soc. Responsib. J. 2012, 8, 561-577. [CrossRef]

15. Jonker, J.; Tap, M.; van Straaten, T. Nieuwe Business Modellen: Een Exploratief Onderzoek naar Veranderende Transacties die Meervoudige Waarde Creëren; Radboud Universiteit: Nimegen, The Netherlands, 2012.

16. Boons, F.; Lüdeke-Freund, F. Business models for sustainable innovation: State-of-the-art and steps towards a research agenda. J. Clean. Prod. 2013, 45, 9-19. [CrossRef]

17. Keizer, A.; Stikkers, A.; Heijmans, H.; Carsouw, R.; van Aanholt, W. Scaling the Impact of the Social Enterprise Sector; McKinsey \& Company Research Report; McKinsey \& Company: Amsterdam, The Netherlands, 2016.

18. Social Enterprise. Sociale Ondernemingen: Wat Zijn Het? Available online: https://www.social-enterprise.nl/over-sociaalondernemen/wat-zijn-het\# (accessed on 6 July 2019).

19. Gandhi, T.; Raina, R. Social entrepreneurship: The need, relevance, facets and constraints. J. Glob. Entrep. Res. 2018, 8, 1-13. [CrossRef]

20. Dacin, P.A.; Dacin, M.T.; Matear, M. Social entrepreneurship: Why we don't need a new theory and how we move forward from here. Acad. Manag. Perspect. 2010, 24, 37-57.

21. Rey-Martí, A.; Ribeiro-Soriano, D.; Palacios-Marqués, D. A bibliometric analysis of social entrepreneurship. J. Bus. Res. 2016, 69, 1651-1655. [CrossRef]

22. Sandberg, J.; Alvesson, M. Ways of constructing research questions: Gap-spotting or problematization? Organ. Sci. 2011, 18, 23-44. [CrossRef]

23. Wilson, F.; Post, J.E. Business models for people, planet (\& profits): Exploring the phenomena of social business, a market-based approach to social value creation. Small Bus. Econ. 2013, 40, 715-737.

24. Phillips, W.; Moingeon, B.; Lehmann-Ortega, L. Social innovation and social entrepreneurship: A systematic review. Group Organ. Manag. 2015, 40, 428-461. [CrossRef]

25. Kerlin, J.A. Social enterprise in the United States and Europe: Understanding and learning from the differences. Volunt. Int. J. Volunt. Nonprofit Organ. 2006, 17, 246. [CrossRef]

26. Sacchetti, S.; Tortia, E. The notion of social responsibility in social enterprises and non-profit organizations. In Corporate Governance: Search for the Advanced Practices, Conference Proceedings, Virtus Interpress; Sumi; 2019. Available online: https: //virtusinterpress.org/IMG/pdf/cpr19p13.pdf (accessed on 1 June 2021).

27. Young, D.R.; Lecy, J.D. Defining the universe of social enterprise: Competing metaphors. Volunt. Int. J. Volunt. Nonprofit Organ. 2014, 25, 1307-1332. [CrossRef]

28. Borzaga, C.; Defourny, J. Conclusions. Social enterprises in Europe: A diversity of initiatives and prospects. In The Emergence of Social Enterprise; Routledge: England, UK, 2001; pp. 350-370. ISBN 9780415339216.

29. Hogenstijn, M. Sociaal Ondernemerschap: Grip op Het Begrip; 2018. Available online: https://www.social-enterprise.nl/oversociaal-ondernemen/publicaties/extern/sociaal-ondernemerschap-grip-op-het-begrip-1005 (accessed on 1 June 2021).

30. Witkamp, M.J.; Raven, R.P.; Royakkers, L.M. Strategic niche management of social innovations: The case of social entrepreneurship. Technol. Anal. Strateg. Manag. 2011, 23, 667-681. [CrossRef]

31. Kerlin, J.A. Defining social enterprise across different contexts: A conceptual framework based on institutional factors. In Social enterprises; Springer: Berlin/Heidelberg, Germany, 2012; pp. 91-117.

32. Santos, F.; Pache, A.-C.; Birkholz, C. Making hybrids work: Aligning business models and organizational design for social enterprises. Calif. Manag. Rev. 2015, 57, 36-58. [CrossRef]

33. Spieth, P.; Tap, M.; van Straaten, T. Value drivers of social businesses: A business model perspective. Long Range Plan. 2019, 52, 427-444. [CrossRef]

34. Saebi, T.; Foss, N.J.; Linder, S. Social entrepreneurship research: Past achievements and future promises. J. Manag. 2019, 45, 70-95. [CrossRef]

35. Hoogendoorn, B.; Pennings, E.; Thurik, R. What do we know about social entrepreneurship: An Analysis of Empirical Research. Int. Rev. Entrep. 2010, 8, 1-42.

36. Canestrino, R.; Raven, R.P.; Royakkers, L.M. Creating social value through entrepreneurship: The social business model of La Paranza. Kybernetes 2019, 48, 2190-2216. [CrossRef]

37. Poledrini, S. Unconditional reciprocity and the case of Italian social cooperatives. Nonprofit Volunt. Sect. Q. 2015, 44, 457-473. [CrossRef]

38. Dacin, M.T.; Dacin, P.A.; Tracey, P. Social entrepreneurship: A critique and future directions. Organ. Sci. 2011, 22, 1203-1213. [CrossRef]

39. Díaz-Correa, J.E.; López-Navarro, M.A. Managing sustainable hybrid organisations: A case study in the agricultural sector. Sustainability 2018, 10, 3010. [CrossRef] 
40. Seelos, C.; Mair, J. Social entrepreneurship: Creating new business models to serve the poor. Bus. Horiz. 2005, 48, 241-246. [CrossRef]

41. Osterwalder, A.; Pigneur, Y. Business Model Generation: A Handbook for Visionaries, Game Changers, and Challengers; John Wiley \& Sons: Hoboken, NJ, USA, 2010; Volume 1.

42. Hedman, J.; Kalling, T. Analysing e-business models. In Towards the Knowledge Society; Springer: Berlin/Heidelberg, Germany, 2003; pp. 259-270.

43. Upward, A.; Jones, P. An ontology for strongly sustainable business models: Defining an enterprise framework compatible with natural and social science. Organ. Environ. 2016, 29, 97-123. [CrossRef]

44. Qastharin, A.R. Business model canvas for social enterprise. J. Bus. Econ. 2016, 7, 627-637.

45. Dees, G. Enterprising non-profits. Harv. Bus. Rev. 1998, 55, 55.

46. Mair, J.; Battilana, J.; Cardenas, J. Organizing for society: A typology of social entrepreneuring models. J. Bus. Ethics 2012, 111, 353-373. [CrossRef]

47. Jabłoński, A. Scalability of sustainable business models in hybrid organizations. Sustainability 2016, 8, 194. [CrossRef]

48. Haigh, N.; Hoffman, A.J. Hybrid organizations: The next chapter in sustainable business. Organ. Dyn. 2011, 41, 126-134. [CrossRef]

49. Epstein, M.J.; Buhovac, A.R. Solving the sustainability implementation challenge. Organ. Dyn. 2010, 39, 306. [CrossRef]

50. Jonker, J. Duurzaam Ondernemen: Naar Een Organisatie-Ecologie Met Het Oog op Duurzaamheid; Radboud Universiteit: Nijmegen, The Netherlands, 2011.

51. Stubbs, W. Characterising B Corps as a sustainable business model: An exploratory study of B Corps in Australia. J. Clean. Prod. 2017, 144, 299-312. [CrossRef]

52. Hoogendoorn, B.; Linssen, M. De Waarde Van Sociaal Ondernemerschap; Panteia: Zoetermeer, Netherlands, 2013.

53. Voinea, C.L.; Dacin, P.A.; Tracey, P. Drivers for Sustainable Business Models in Start-Ups: Multiple Case Studies. Sustainability 2019, 11, 6884. [CrossRef]

54. Lambert, S. A business model research schema. BLED Proc. 2006, 7, 43.

55. Margiono, A.; Zolin, R.; Chang, A. A typology of social venture business model configurations. Int. J. Entrep. Behav. Res. 2018, 24, 626-650. [CrossRef]

56. Kiers, J. Social Enterprises: How to Turn a Problem into an Opportunity; Erasmus University: Rotterdam, The Netherlands, 2015.

57. Defourny, J.; Nyssens, M. Fundamentals for an international typology of social enterprise models. Volunt. Int. J. Volunt. Nonprofit Organ. 2017, 28, 2469-2497. [CrossRef]

58. Eisenhardt, K.M.; Graebner, M.E. Theory building from cases: Opportunities and challenges. Acad. Manag. J. 2007, 50, 25-32. [CrossRef]

59. Yin, R. Case Study Research and Applications: Design and Methods; Sage Publications: Thousand Oaks, CA, USA, 2018.

60. Hancock, D.R.; Algozzine, B. Doing Case Study Research: A Practical Guide for Beginning Researchers, 3rd ed.; Teachers College Press: New York, NY, USA, 2017.

61. Dawson, H.R.; Algozzine, B. Doing Case Study Research: A Practical Guide for Beginning Researchers, 1st ed.; Teachers College Press: Bogota, Colombia, 2006.

62. Baarda, D.B.; de Goede, M.P.M.; Teunissen, J. Basisboek Kwalitatief Onderzoek: Praktische Handleiding voor het Opzetten en Uitvoeren van Kwalitatief Onderzoek; Stenfert Kroese: Amsterdam, The Netherlands, 2001; Volume 2.

63. Social Enterprise NL. De Social Enterprise Monitor 2018; Social Enterprise: Amsterdam, The Netherlands, 2018.

64. Osterwalder, A. The Business Model Ontology a Proposition in a Design Science Approach; University of Lausanne: Lausanne, Switzerland, 2004.

65. Zahra, S.A.; Dacin, P.A.; Tracey, P. A typology of social entrepreneurs: Motives, search processes and ethical challenges. J. Bus. Ventur. 2009, 24, 519-532. [CrossRef]

66. Saunders, M.; Thornhill, A. Methoden en Technieken van Onderzoek; Pearson Benelux: Amsterdam, The Netherlands, 2019.

67. Voinea, C.L.; Roijakkers, N.; Ooms, W. Be authentic, follow through, and think holistically: Editorial thoughts on the virtuous circle that is sustainable innovation. In Sustainable Innovation; Routledge: Oxfordshire, UK, 2021; pp. 3-16.

68. Rauf, F.; Raven, R.P.; Royakkers, L.M. How executive turnover influences the quality of corporate social responsibility disclosure? Moderating role of political embeddedness: Evidence from China. Eurasian Bus. Rev. 2021, 5, 1-25. [CrossRef]

69. Voinea, C.L.; Moingeon, B.; Lehmann-Ortega, L. The Relation between environmental management systems and environmental and financial performance in emerging economies. Sustainability 2020, 12, 5309. [CrossRef]

70. Wevers, H.T.; Voinea, C.L. Corporate Social Responsibility as Core Competence for the Business Model of Social Start-Ups in the Netherlands. Eur. J. Sustain. Dev. 2021, 10, 23. [CrossRef] 